\title{
A Critique of the Language of Law in Selected Court Cases in Nigeria
}

\author{
K. B. C. Ashipu \\ Department of English \& Literary Studies, University of Calabar, Calabar, Cross River State, Nigeria \\ Kbashipu@yahoo.com, 08036901850
}

Gloria M. Umukoro

Department of Modern Languages and Translation Studies University of Calabar, Calabar, Cross River State, Nigeria

\section{Doi:10.5901/mjss.2014.v5n8p622}

\section{Abstract}

This paper examines the language of Law, technically known as legalese. Legal matters are normally written in a specific language using registers that are peculiar to law. Since law aims at precision, legalese are used to avoid generalization. The ordinary person who is outside the law profession is not familiar with legalese. The objectives of this study therefore, are to examine the language of law in selected court cases in Nigeria and explicate the semantic implication of legalese that are used to convey such cases to the understanding of the layman. Lawyers use abstract words and this is their professional way of language use. In view of this, the paper shall equally examine these abstract words used by lawyers in the course of speaking and writing legal documents. The paper concludes that this professional way of language use bequeaths on the language of law a peculiarity that is different from other varieties.

Keywords: Legalese, Defendant, Plaintiff, Judge, Lawyer

\section{Introduction}

One of the many areas in human activities where language plays a vital role is law. Legal activities have been very dominant in the life of man and lawyers, judges and even defendants employ language as a weapon to articulate their views. This variety of language is technically known as Legalese. Lawyers use legalese in court for the purposes of argument and advancement of the interest of their clients. Thus, studying the forms of legalese used by lawyers to persuade the court is important for a variety of reasons namely; that law is the watchoog of the society and so legalese which constitutes its register should be critically studied to explicate its semantic implication, to unmask it for easy understanding by the layman and also to enrich specifically the subject area of English for Specific Purposes and Stylistics. Against this background therefore, the paper investigates the use of language in selected court cases in Nigeria with a view to discovering how this peculiar variety of language achieves the purposes of precision and persuasion which is the major target of Lawyers. The paper is structured into six parts; the introduction, a description of the language of law, objective of the study, Data presentation and analysis, conclusion and recommendations.

\section{Objective}

The objective of this study is to examine critically the language of law as a special variety of language use. Legal matters are normally stated in a specific style using terms that are peculiar to only law. These terms are known as legalese. The subject of Legalese is hardly studied with vigour even in the course of English for Specific Purposes which studies the varieties of language use in various fields of human endeavour. Yet there is a need for the study of this variety of language because of its peculiar creativity and uniqueness. The present research is specifically devoted to the study of this variety of language in order discover what makes the variety unique and peculiar to only the profession of Law.

\section{The Language of Law}

Legalese is a jargon characteristically used by lawyers for legal writing which may be difficult for laymen to understand. It is a variety of language use that is peculiar to legal practitioners. Legal writing tends to have very unusually long 
sentences with many carefully phrased clauses and features of legal writing that make it resistant to misinterpretation. When legalese documents are read by non legal practitioners, they are often difficult to comprehend or even deceptive for those without legal training (Moore, 2010:14). Unlike ordinary writing, legal writing is aimed at a highly specialised group that uses a specialised vocabulary, containing both unusual and common terms imbued with technical meanings. As a result, the researcher asserts that sentences in legal documents are often very lengthy and complex. For this reason, legal writing has often been criticised as an obtuse exercise that encourages the perception that lawyers speak in rhetoric that is without substance ( 2012:115).

Since the latter half of the $20^{\text {th }}$ Century, many legal scholars have encouraged writers to eliminate old fashioned terms and phrases in favour of explicit and shorter forms. For instance, an expression such as"part of the first part and party of the second part" can be replaced with" plaintiff and defendant" respectively. Legal writing is also a variety of technical writing that has been developed to meet the needs of legislators, lawyers and judges to express their desired application of the law. Legal writing consists of a distinctive style, and large terminologies are derived from Latin, French and English (Allen, 2013:229). Furthermore, Blackstone (2012:113) who quoted Williams (1969:65) asserts that "certain technical terms were not capable of English dress with any degree of seriousness". Writing on the history of legal language, Alabi (2013:12) quotes Crystal (1969:195) as saying: "during its development legal English has had to rub shoulders with and sometimes give way to both French and Latin. French and Latin loan words continued to be used in writing legal documents from the period when Anglo-Norman was the language of the courts. Legal language is generally either informative or persuasive. A persuasive document such as a motion or brief, attempts to persuade the fact finder of the most appropriate interpretation of such language. Sometimes a communication gap arises from the technical language. Here the vital role of law in our society becomes handicapped in some cases. According to Gilman (2012:119)

Involved here is the communication of vital information. The dull language of law - its bewildering syntax and other faults of grammar, its less than forthright expression, its substitution of can't for vocabulary is paralysing communication... the problem does not only lead to technological devices that will not work but to an ability to discuss intelligently.

The language of law is obscured because of its jargons, ambiguity and inaccuracy. The resultant problem is that those who are not in the legal profession, find it difficult to comprehend such a language variety. Hence, even in a situation where the information that concerns them is vital, it is neglected due to their inability to understand the language.

To speak of legal English as communicating meaning is in itself misleading. Of all the varieties of language, it is perhaps the least communicative in that it is designed not to enlighten the users of language at large. According to Maxwell(2013:11), Legal writers pushed into oddity by their attempt to be unambiguous and as it were, in the same direction by the knowledge that since their productions are for the benefit of someone familiar with the jargons as themselves they do not need to bother much about the general public. Crystal (2013:96) avers this variety of language use when he asserts:

Lawyers have been doing basically the same things - conveyance of property, drawing up wills and so on - for a long time and for each species of transaction there are developed formulae or rather collections of such formula - which are known to do the job adequately, having been subjected to long and thorough testing before the courts. There is a strong motivation for any lawyer to turn to a form of words that he knows he can rely on, rather than take a chance of concocting something entirely new which many turn out to have unsuspected deficiencies. Therefore much legal writing is by no means spontaneous but is copied directly from "form books" as they are called in which establish formula are collected ... legal English are so unlike normal discourse that are not easily generated even by experts. It is a form of language, which is about as far removed as possible from informal spontaneous conversation.

Quirk (2012:19) emphasises that the lawyers must absolutely eschew words that have colour, and content themselves with the "herein before" and "aforesaid" in order to achieve precision. The lawyer neither wants to be obscure nor make his documents too easy to be read. Gasiokwu(2010:81) asserts that it is possible to express laws in highly specific language that provides details of every aspect of the relationship that law seeks to regulate. But viewed from another perspective, one sees clearly the difficulty of expressing all statutory rules in very detailed way.

Another major characteristic of legal language is the use of abstract concepts which do not take their meanings from sensed experience, but are normative in character. Concrete words convey meaning more plainly than abstract words. Lawyers are generally notorious for vague abstractions. They argue that since the law itself contains so many abstractions they must use abstract words. According to White (2011:81), legal writing requires ability to present an issue in an honest and straight forward manner. Since facts are sacred, what is to be understood must be factual to the point. The factual situation must not be confused by the use of unnecessary style. Accuracy therefore, is a product of language and also of the exclusion and inclusion of emphasis and subordination. Proper stressing of important ideas and the subordinate of less important ones is the key to successful legal writing. Brevity is important in legal writing, as one's writing will be more likely to be understood and remembered if it is brief. Writing that is brief and accurate has a good 
start towards clarity( Collins 2013:21) Based on this description of the language of law we shall now proceed to analyse the use of legal register in the actual documents of selected court cases in Nigeria .

\section{Method(s) of Data Collection}

The workshop which was organised by the National Judicial Commission and which attracted judicial officers from various regions of the country provided the material for writing the paper. The theme of the workshop was "Writing skills, Recording and Documentation". The writer of this paper was a facilitator and he presented a paper on writing skills. Some court documented cases were made available during the workshop for critical assessment and the writer observed a peculiar and consistent pattern of written expressions by the judicial officers in the documents. The writer became curious and decided to do a research on this variety of language use. The writer then extracted some data from these documents (but with the permission of the judicial officers) which were used for this analysis. The writer also visited some of the courts to obtain more data and with the co-operation of the court registrars the writer had access to the data that were collected for this paper. Although the data to be analysed below were collected from the courts, some library material was also consulted to complement the research.

\section{Data Presentation and Analysis}

The following excerpts to be analysed were taken from some of the cases that were lodged and determined in selected courts in Nigeria. In marshalling the forces of language to achieve his aim, the lawyer engages in an array of legal jargons aimed at persuading the court to grant his client's request. In examining the style of legalese in a divorce suit for instance, we shall analyse the lawyer's choice of words in an attempt to discover the extent to which language has been used in court, which is meant to be informative, persuasive and precise. The main conflict in the following suit is a request by the complainant who is seeking dissolution of marriage and custody of the children against the defendant. Her desire is for the court to see the wrong done to her and the lawyer served the defendant the following document on her behalf;

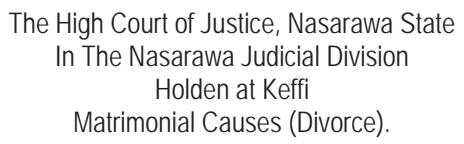

\section{Between}

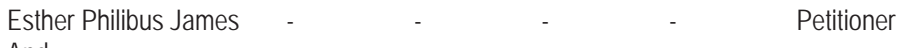

And

... For a Degree of dissolution of marriage and also seeking orders with respect to the three children of the marriage...

In the illustration above, words and phrases like 'Holden', 'Decree', 'petitioner', 'respondent' and 'orders' are used to depict a court atmosphere and the language of law. The excerpt above is part of what the petitioner, through the lawyer, said in the court. These legalese may conceal the intended message (from the respondent) because the respondent is not learned in the language of law and so cannot interpret such jargons and can also not comprehend the underlying meaning. Hence, the services of a lawyer become necessary. However, these words, phrases and sentences have specialized meaning within the legal context. This further implies that the power of legal language lies in its ability to entice both the court and the listener(s) the "Plaintiff's counsel" further stated thus: .... If you desire:

(a) To deny any facts alleged in the petition,

(b) To allege any additional facts for the consideration of the court

(c) To submit to the court that it should dismiss any of the proceedings instituted by the petitioner, or

(d) To make any other submission to the court ... you should file an answer to the petition.

In the above excerpt, although the speaker's counsel is presumed to know that the listener is guilty of the allegation, he employs a device of options for the respondent to give room for fair hearing as peculiar to the court. This is why the conditional phrase "if you desire" was used to present such options to the respondent. The lawyer's major device here is repetition for the purposes of emphasis, as contained in words and phrases like 'to', 'allege', 'to deny', 'to allege', 'to submit' and 'to make'. The lawyer repeatedly uses the above legalese to convince and elicit information or reaction from the respondent. Thus, repetition and choice of words are mere manipulations of language to induce the respondent to react to the summon.

The Plaintiff's lawyer further submitted that, 
.... The petitioner, then a spinster, was lawfully married to the respondent ... surname of the petitioner immediately before marriage was Esther Philips ... Within the act domiciled in Nigeria.

Legalese such as "the petitioner", "lawfully married" "respondent", "act" and 'domiciled' are used to typify a litigation which the plaintiff instituted against the respondent because she was lawfully married before the marriage became problematic. The marriage was conducted under the Matrimonial law and now, the Plaintiff seeks divorce as illustrated thus:

... An order is hereby sought for to end the marriage on the ground of in-human treatment, lack of care and affection and coupled with irreconcilable differences. The petitioner cannot live with the respondent any longer. The petitioner is seeking for custody of the third child of the marriage still living with the respondent

This excerpt is to convince the court and persuade the respondent to see reasons why the marriage should be dissolved. On the basis of this information, there is an array of legalese which include 'order sought', 'respondent', 'custody', 'seeks', 'petitioner', 'decree'. It is interesting to note that the word "decree" is used here. It is mostly used by the military to make strong pronouncements on their subjects and it is also used by legal practitioners as a special aspect of law.

Often communication gaps arise from the use of legal jargons and, according to Gilman (2012:215,

.... Involved here is the communication of vital information. The obscure language of law, its bewildering syntax and other faults of grammar, its less forthright expression, its substitution of cannot for vocabulary is paralyzing communication... The problem does not only lead to technology devices that will not only lead to an inability to discuss intelligently...

The defendant's counsel employed all legal devices to persuade the respondent to respond to the suit and as expected, the listener responded in affirmative by acknowledging the suit and by admitting that he was the one being referred to in the suit as seen below:

I .... Acknowledge, that on the ... day of ... 1997 at .... Received:-

(a) Sealed copy of petition in these proceedings

(b) Notice of petition addressed to me. I also acknowledge that I am the respondent and I am the person whom the notice of petition is addressed to.

The respondent's acknowledgement of the suit implies that there is a case to be argued and resolved.

It should also be noted that in one of the excerpts above the respondent was given several options namely; to institute a suit against the allegation, to deny the allegation or submit his own suggestion to the court. This further informs us about the nature of the judicial system which operates on fair learning. The lexical terms in the excerpt above confirm the prevalence of legalese in court.

'I .... Acknowledge'

'I received

'I ... notice of petition addressed to me'

'... I also acknowledge', ' I am the respondent',

I am the person, etc.

The extensive use of the first person pronoun 'I' depicts the level of the listener's personal involvement in the case. The first person pronoun ' $I$ ' is used by lawyers for the purposes of emphasis and to specify the case. Although we have argued that legalese are not commonly used, some are carefully used by lawyers depending on their relevance to the subject matter, for example in criminal and divorce cases which we have already discussed.

Our next concern in this paper is to discuss legalese which are used in criminal cases. The following excerpt is taken from a criminal case of murder.

In the High court of Justice of Nasarawa State, Nigeria

Holden at Keffi

Motion No.16

Case No. 5

Between

State

And

Ara Giwa

Rules 1970

... (Application for leave to prefer a charge in the High Court)

Complainant/Applicant

Accused 
Whereas: The accused person was arrested on or about the 10th day of September, 2002, for the alleged offence of culpable homicide punishable with death, contrary to section 221 of the Penal Code.

In the above illustration, words and phrases like 'Holden', 'Motion no', 'Case no', 'State', 'Complainant / applicant', 'charge' accused, whereas, 'on or about', 'alleged', 'offence' 'culpable' homicide', section 221 and 'Penal Code' are used to depict a court atmosphere and criminal case. The words 'state' (instead of the family of deceased) and Nasarawa State are used to show that anybody who takes the life of a fellow citizen commits an offence against the society and not an individual. The lawyer in this case is in the service of the State Government and the matter in the court involves a human life. The phrase 'culpable homicide' means unlawful killing, which has its punishment as death except if proved otherwise. The Attorney - General read the charge against the murderer as:

That you, Ara Giwa, on or about the $10^{\text {th }}$ day of September, 2002 at Yaka Lafiya, Karu Local Government Area, within the jurisdiction of the Court, did commit culpable homicide punishable with death in that you caused the death of Dauda Titiya by doing an act, to wit: beating him with a stick with the knowledge that his death would be the probable consequence of your act and thereby committed an offence punishable under section 221 of the Penal Code.

This illustration shows the allegation otherwise referred to as the 'charge' in a criminal case.

One distinguishing characteristic between the language of law and other varieties of language is the specificity in which words are supposed to function for the purposes of persuasion and precision. Hence, we see the use of legalese such as 'charge', jurisdiction, culpable homicide, 'on act', 'to wit', attorney-general and penal code, to depict a language typical of law in a High Court where preliminary investigation on a criminal case has been going on to determine whether the accused actually killed the deceased. In order to convince the court, the defence counsel must establish by evidence that the accused person caused the death of the deceased intentionally. Accordingly, words and phrases such as 'criminal case', burden of proof', 'prosecution', 'prove', 'guilty' 'accused', offence 'conviction', evidence, 'act' are jargons which point out that the court is in session and that both the State counsel, the accused, the witnesses and the judge are involved. These jargons imply that before an accused person is convicted in a criminal case, the prosecution is saddled with the responsibility of establishing the fact that encompasses all the parties involved.

\section{Conclusion}

We set out in this paper to investigate the language of law in selected cases. The specific intention was to analyse the legalese used in presenting the cases in order to discover the extent to which the language creates impact on the judge and the judgments that are delivered. A number of features in the use of legal language were identified. It is clear that the business of the lawyer is to manipulate legal jargons for the purpose of convincing the court in order to win a case for his client. He does this by a careful selection of words, which gives his language a peculiarity of the language of law. It was discovered that the language of law is highly technical. Although it is intended to be informative and persuasive, but not much has been achieved, as the layman cannot interpret the language of law without the help of a legal practitioner. This variety of language use does not enhance the layman's understanding of the court proceedings because the language lacks clarity and brevity. It is odd, dull, vague, obscure and ambiguous.

\section{References}

Alab,UA 2013. Stylistic features of the legal discourse.In. Adebayo Lawal (Ed.). Stylistics in theory and Practice. Ilorin: Paragon Books. Allen,G 2013. Common Law. London: Oxford University Press.

Ashipu KBC 2012. Introduction to Rhetoric. Onukaogu (Ed.) Communication in English for Polytechnics and other Colleges. 9th edition. Calabar: BON Universal Limited.

Blackstone M 2012. Dictionary of Legal Terms. 11 th edition. London: Oxford University Press.

Collins P 2013. Style and Stylistics. London: Methuen

Crystal D, Davy D.2013. Investigating English style. 13 ${ }^{\text {th }}$ edition. London: Longman Press.

Crystal D. 2011. Varieties of English. Oxford: Oxford University, University Press.

Doherty O 2013. Legal Practice and Management in Nigeria.3rd edition. Britain: Biddle Limited.

Gasiokwu MU 2010. Legal Research and Methodology.4th edition. Nigeria: Feb. Anieh.

Gilman W 2012. The Language of Law. London: English University

Maxwell, E 2013. Legal Drafting. London: Oxford University Press

Moulton W 2012. Language and Human Communication Concepts and Process. New Jersy: Princeton.,

Moore WH 2010. Principles and Procedures in the Administration of Justice. California: John Wiley and Sons Inc.

Quirk R Greenbaum S 2012. A University Grammar of English 14 ${ }^{\text {th }}$ edition. London: Longman.

White D 2011. Legal Drafting. Kant; Metheun 